\title{
Letramento na EJA: o que revelam os diários de campo das práticas de docência do Curso de Pedagogia?
}

\author{
Sonia Maria Chaves Haracemiv* \\ Veronica Branco**
}

\section{Resumo}

Este artigo tem como objetivo apresentar uma pesquisa das práticas de letramento observadas, diagnosticadas e registradas nos Diários de Campo pelos licenciandos do Curso de Pedagogia da Universidade Federal do Paraná das salas de aulas multisseriadas, Educação de Jovens e Adultos (EJA), nas escolas da rede municipal de Curitiba. Tratase de um estudo qualitativo com orientaçóes de pesquisa-ação, no qual vem sendo investigada a relaçáo entre a concepçáo teórica de letramento dos acadêmicos e a concepção prática vivida nas salas de aula de na disciplina de Prática de Docência dos anos iniciais do Ensino Fundamental. Nesta pesquisa, os registros analisados indicam a necessidade de que os professores regentes de EJA e estagiários conheçam as práticas de letramento nas quais seus alunos se inserem, organizando a prática pedagógica interventiva, de forma que o letramento na EJA parta do letramento das relaçóes sociais, com possibilidades de ampliação da participação e emancipação do jovem e adulto, pela compreensão das dimensôes contextuais do mundo em que vive, sendo que o falar e o escrever sejam significativos para os sujeitos que as realizam.

Palavras-chave: Educação de Jovens e Adultos. Prática de Docência. Letramento.

\footnotetext{
* Doutora em Educação Pontifícia Universidade Católica de São Paulo (PUC/SP). Professora da Universidade Federal do Paraná (UFPR).

** Doutora em Educação pela Universidade Federal do Paraná (UFPR). Professora do Curso de Pedagogia e do Programa de Pós-Graduação em Educação na UFPR.
} 


\section{Introdução}

A pesquisa teve como foco a análise e discussão das práticas de letramento empregadas pelos docentes nas escolas da comunidade, e registradas pelos estagiários do Curso de Pedagogia em seus Diários de Campo. Considerou-se os registros e as concepçóes teóricas e práticas desse processo e, a forma como essas práticas vão constituindo elementos didático-pedagógicos na formação inicial dos(as) estagiários e continuada dos docentes que atuam nas classes de Educação de Jovens e Adultos (EJA) de $1^{\circ}$ ao $4^{\circ}$ ano do Ensino Fundamental, no período noturno, das escolas da rede municipal de Curitiba que ofertam a EJA. Escolas essas que são campo de formação do curso de Pedagogia da Universidade Federal do Paraná - UFPR.

Sendo a formação do professor(a) de Jovens e Adultos de responsabilidade dos(as) professores da Universidade, considerou-se que a partir das práticas pedagógicas conscientes o docente pode atender a necessidade dos indivíduos iletrados, possibilitando ao licenciando o desenvolvimento da consciência pedagógica de que a leitura e a escrita são instrumentos básicos para o ingresso e a participação plena na sociedade letrada, a qual, muitas vezes, não é oportunizada aos jovens e adultos que não dominam essas habilidades.

O estudo foi organizado de forma a revelar a compreensão das relações entre as concepçóes e práticas de letramento vivenciadas nos contextos das salas de aula de jovens e adultos, e as teorias aprendidas no âmbito da Universidade. Este estudo exigiu das pesquisadoras, que são docentes da disciplina de Prática Pedagógica B - Estágio em Docência nos anos iniciais do Ensino Fundamental, retomarem, numa abordagem de pesquisa-açáo, as leituras e discussóes sobre questóes relacionadas à alfabetização e letramento na EJA, levando em conta, num primeiro momento, as concepçóes estudadas nas disciplinas de Alfabetização na Educação Infantil e no Ensino Fundamental, e Alfabetização em EJA (disciplinas obrigatórias) e Processo de Aprendizagem na Educação de Jovens e Adultos (disciplina optativa).

Para discutir a temática, letramento na Educação de Jovens e Adultos, revelados na leitura dos Diários de Campo, construídos durante o estágio de docência, foram formuladas questôes norteadoras no trabalho de pesquisa, tais como: Qual o enfoque teórico da alfabetização e letramento presente na EJA? O que revelam os Diários de Campo o processo de alfabetização/letramento na prática pedagógica com jovens e adultos? Qual o alcance da proposta de 
intervenção dos (as) estagiários (as) no letramento, como primeiras experiências (formação inicial) na EJA?

Essa leitura analítica e crítica teve como objetivo repensar a orientação e acompanhamento das etapas de observação, registro e diagnóstico, que subsidiaram a elaboração do Diário de Campo. Assim sendo, a metodologia de pesquisa de leitura e análise dos registros buscaram refletir, com todos os envolvidos no processo de formação docente professores da UFPR, regentes de classe, educandos estagiários e jovens e adultos, sobre a produção de conhecimento didático-pedagógico e verificar até que ponto os elementos observados, diagnosticados e registrados subsidiaram a superação das práticas pedagógicas tradicionais, no tocante ao planejamento e às intervençóes pedagógicas, objetivando identificar se houve superaçóes e/ou reproduçôes das práticas de letramento nas classes de EJA.

\section{Enfoque teórico de alfabetização e letramento na EJA}

A princípio breves discussôes sobre os conceitos de alfabetização e as relações com os conceitos de letramento serão apresentadas, com o objetivo de apontar reflexôes com base em situaçóes pedagógicas de letramento na EJA.

Considerando a sociedade centrada na circulação de informaçôes, conhecimentos, exposição de imagens e escritas, a pessoa alfabetizada, que apenas sabe ler e escrever, que só identifica os códigos, não atende as demandas atuais. É preciso apropriar-se da funçáo social da leitura e da escrita, isto é, letrar-se para viver plenamente a cidadania, condição necessária para participar da vida em sociedade, que altamente urbanizada e informatizada do século XXI exige um domínio cada vez maior da leitura e da escrita. Esse domínio exige da escola um ensino centrado nas relaçóes entre sujeitos sociais.

No Brasil, o analfabetismo é um problema não resolvido, revelado na Pesquisa Nacional por Amostra de Domicílios (Pnad) e do Instituto Brasileiro de Geografia e Estatística (IBGE), onde a taxa de analfabetismo das pessoas de 15 anos ou mais foi estimada em $8,7 \%$, o que correspondeu ao contingente de 13,2 milhōes de analfabetos. Em 2011, essa taxa era de 8,6\%, no contingente de 12,9 milhões de pessoas, e em 2007 a taxa de analfabetos naquele segmento etário era de $10 \%$, em um contingente de 14 milhóes de pessoas. Portanto, ainda que as taxas percentuais variem para um pouco menos ou um pouco mais, ao longo dos últimos anos, ainda é muito grande o número absoluto de analfabetos (BRASIL, 2012). 
Os índices apresentados revelam que mantido esse ritmo de redução do analfabetismo, ainda levará várias décadas para o Brasil incluir todos os brasileiros entre a população letrada. O que faz com que, a pretensão do governo federal em reduzir pela metade a taxa de analfabetismo no país até 2015, chegue ao percentual de 6,7\% (HADDAD, 2012).

O problema do analfabetismo brasileiro tem se agravado pela falta de políticas públicas, e pela [...] falta de consciência social, pois, parece haver certa invisibilidade desse tema, como se pudéssemos marginalizar milhóes de brasileiros. Náo é um problema residual, nem do passado, mas que se repete a cada dia (DI PIERRO, 2010, p. 27-33).

A alfabetização de jovens e adultos no Brasil vem sendo desenvolvida através de campanhas contra o analfabetismo, pois, a mesma sempre representou um dos grandes problemas sociais do país. Frente ao contexto histórico social da realidade brasileira é preciso rever teoricamente a concepção de alfabetização. Para tanto, faz-se necessário revisitar o termo constituído historicamente em diferentes momentos, principalmente em se tratando de alfabetização de adultos, já que essa modalidade se desenvolveu tardiamente, até porque o ensino da leitura e da escrita era pensado predominantemente para as crianças das elites dominantes (CIRINO; HARACEMIV; SOEK, 2010).

Quanto ao conceito de alfabetização de jovens e adultos, até meados dos anos oitenta, mesmo havendo tendências diferentes, as palavras alfabetizaçáo, alfabetizado, tinham um significado relativamente consensual entre profissionais da educação e até mesmo entre a população leiga, de que "alfabetizado era aquele que sabia ler e escrever". Já a alfabetização, definia-se como o "processo de ensinar e/ou aprender a ler e a escrever" (SOARES, 2003, p. 9). Porém, as pesquisas têm demonstrado que o conceito de alfabetização vem sofrendo expressivas alteraçôes ao longo das seis últimas décadas, como afirma Soares (2003, p. 9):

Até a década 50, era considerada alfabetizada a pessoa que tivesse a habilidade de ler e escrever um texto simples e que dominasse o código alfabético. A partir da década de 70 a UNESCO passou a utilizar o termo "analfabetismo funcional", que corresponde ao fenômeno no qual a pessoa sabe ler e escrever, mas náo alcança o domínio 
social da leitura e da escrita, alertando para a necessidade de se estender a todos o acesso à escolarização básica, a fim de se garantir tal domínio. Desde então, vêm sendo adotados diversos acordos e planos internacionais que aprofundaram esse entendimento relacionando-o à diversidade cultural e à educação ao longo de toda a vida.

Isso revela a ampliação dos conceitos de alfabetização. Os últimos censos empregam o termo "alfabetizados funcionais", como um novo conceito que se acrescenta ao de alfabetizado, tomando como critério o nível de escolaridade atingido ou a conclusão de anos de estudo, em geral, o quarto ano do Ensino Fundamental, o que dá a ideia de que o acesso ao mundo da escrita exige o uso de mais habilidades, para aprender a ler e a escrever. Assim sendo, a definição de alfabetismo funcional se utiliza do critério, "anos de escolaridade" como acréscimo ao conceito de alfabetização como "saber ler e escrever" ou "saber ler e escrever um bilhete simples" (SOARES, 2003, p. 10-12).

A ressignificação do conceito de alfabetização trouxe também a palavra letramento, como:

[...] o conceito de que a inserção no mundo da escrita se dá através de dois processos: a aprendizagem do sistema de escrita (o sistema alfabético e o sistema ortográfico) - o que se poderia denominar alfabetização, em sentido restrito [...] e o de uso efetivo desse sistema em práticas sociais que envolvem a língua escrita (SOARES, 2003, p. 15, grifo do autor).

Esse conceito leva a compreensão de que novas palavras aparecem quando novas ideias ou novos fenômenos surgem. O desenvolvimento e humanização dos sujeitos podem ser observados quando a alfabetização se dá pela "apropriação da leitura vinculada com uma nova condição humana, com a capacidade de se envolver e participar em novas práticas políticas, sociais e culturais" (ARROYO, 2005, p. 20).

$\mathrm{Na}$ concepção freiriana, a alfabetização tem um significado mais abrangente, na medida em que vai além do domínio do código escrito, pois, enquanto prática discursiva possibilita uma leitura crítica da realidade, constitui-se como um importante instrumento de resgate da cidadania e reforça o engajamento do cidadão nos movimentos sociais que lutam pela melhoria da 
qualidade de vida e pela transformação social (FREIRE, 1991), e defende a ideia de que a leitura do mundo precede a leitura da palavra, portanto a alfabetização do sujeito deve possibilitar uma leitura crítica do mundo no qual está inserido. Assim, no trabalho pedagógico com a alfabetização, além de ensinar o código alfabético, deve-se ensinar uma maneira de ler e interpretar o mundo, pela qual são repassados, valores, ideologias e crenças. Dessa forma, mais do que ensinar a ler e a escrever o alfabetizador deve ensinar seus alunos a fazerem a "leitura de mundo", com palavras que pertençam ao mundo dos jovens e adultos.

Nesse sentido, é de fundamental importância que a opção metodológica adotada leve em conta o alfabetizando jovem e adulto, ou seja, considere sua condição de falante competente da língua para os usos cotidianos, bem como, a riqueza e a variedade de experiências, saberes e interesses, que considere a origem regional, valorizando a sua linguagem, evitando a infantilização ou criaçáo de linguagem artificial e propicie o exercício da imaginação e da criatividade, tanto na oralidade quanto no uso da palavra escrita (CIRINO; HARACEMIV; SOEK, 2010).

É preciso resgatar o próprio conceito de linguagem, pois ao longo da história da educação brasileira a tarefa de alfabetizar se reduziu ao "domínio do sistema gráfico", como a aquisição de um código ou de uma habilidade que pudesse apenas ser treinada (PERREIRA, 2005).

$\mathrm{Na}$ busca de fazer uma alfabetização de adultos que leve, efetivamente, ao domínio da linguagem escrita e não só da técnica da escrita e buscando inserir, de modo mais completo, o jovem o adulto no mundo da escrita, as experiências tomam consistências diferentes e vão construindo novos paradigmas. Com isto, percebe-se que o primordial é a inclusão social do jovem ou do adulto na sociedade letrada em geral, e não o de colocá-los como indivíduos isolados no processo educativo (PERREIRA, 2005).

Essa inclusão deve acontecer antes e durante a alfabetização e continuar por toda sua vida, porque as habilidades de leitura e escrita deixaram de ser vistas como o simples desenvolvimento de habilidades motoras para assumirem o papel de habilidades culturais e sociais necessárias à vida de todo cidadão.

A partir dos anos 80 do século XX, aparece no Brasil, no campo da alfabetização, a vinculação do termo "letramento". Esse termo é uma tradução da palavra inglesa literacy que deriva do latim littera, que significa letra, mais o sufixo $c y$ significa qualidade, condição, estado, ou seja, literacy é considerado o 
estado ou condição do indivíduo que sabe a ler e escrever e utiliza a leitura e a escrita de forma competente (SOARES, 2003).

Letramento, assim, é compreendido como estado em que o indivíduo vive, e não só saber ler e escrever, mas exerce as práticas sociais de leitura e escrita no contexto em que vive, sabendo ler jornais, revistas, livros, bem como, ler e interpretar tabelas, como por exemplo, as de vacinas de seus filhos, calendário, cronograma de turno de trabalho, quadros e formulários, entendendo como preenchê-los, os registros e documentos, como identidade, carteira de trabalho, redigir um ofício, um requerimento, ler as alíquotas cobradas nas contas de água, luz, telefone, escrever cartas, bilhetes, telegramas sem dificuldade, até redigir digitalmente. Assim, um indivíduo pode ser mais ou menos letrado de acordo com seu grau de envolvimento nessas práticas sociais de letramento, em contextos específicos (SOARES, 2003).

Segundo Kleiman (1995, p. 19), letramento é um conjunto de práticas sociais que usam a escrita enquanto sistema simbólico e tecnológico, em contextos específicos para objetivos específicos. Já para Marcuschi (1995) letramento é o uso da escrita na sociedade e pode ir desde uma apropriação mínima da escrita, tal como o indivíduo que é analfabeto, mas sabe o valor do dinheiro, sabe o ônibus que deve tomar, sabe distinguir as mercadorias pelos ícones das marcas, e sabe muitas outras coisas, mas não escreve e nem lê regularmente. Portanto,

[...] dissociar alfabetização e letramento é um equívoco porque, no quadro das atuais concepçóes psicológicas, linguísticas e psicolinguísticas de leitura e escrita, a entrada da criança (e também do adulto analfabeto) no mundo da escrita se dá simultaneamente por esses dois processos: pela aquisição do sistema convencional de escrita - a alfabetizaçáo, e pelo desenvolvimento de habilidades de uso desse sistema em atividades de leitura e escrita, nas práticas sociais que envolvem a língua escrita - o letramento (SOARES, 2003, p. 15).

Segundo Soares (2003), alfabetização e letramento não são processos independentes, mas interdependentes, e indissociáveis: a alfabetização se desenvolve no contexto de, e por meio de práticas sociais de leitura e escrita, isto é, através de atividades de letramento, que por sua vez, só pode se desenvolver 
no contexto da, e por meio da aprendizagem das relações linguísticas, como o reconhecimento das relaçôes fonema-grafema, isto é, em decorrência do processo de alfabetização. Pode-se observar que as reflexôes sobre alfabetização/letramento na EJA, vão além de um mero processo de aprendizagem da leitura e escrita, dando perspectivas para o indivíduo rever sua forma de estar no mundo como cidadão, devendo ser um processo de luta pela,

[...] humanização, pelo trabalho livre, pela desalienação, pela afirmação dos homens como pessoas, como 'seres para si', [...] significação. Esta, somente é possível porque a desumanização, embora seja um fato concreto na história, não é, porém, destino dado, mas resultante de uma 'ordem' injusta que gera a violência dos opressores e esta, o ser menos (FREIRE, 1987, p. 30).

Isso implica que o processo de tomada de consciência da condição sóciohistórica por parte do jovem e adulto encontre "fecundidade à medida que possa haver a humanização, por meio do resgate da memória, da solidariedade e, de igual modo, pela libertação das máscaras sociais, que alienam e aprisionam" (FREIRE, 1987, p. 30).

\section{Os registros do Diário de Campo revelando a prática pedagógica com jovens e adultos no processo de alfabetização/letramento...}

Construímos nossa teoria ao aprendermos a ler nossas experiências propriamente dita. Construímos nossa teoria quando fazemos perguntas aos autores; quando não nos satisfazemos com as primeiras respostas e com as experiências e começarmos a nos perguntar sobre as relaçôes, os motivos, as consequências, as dúvidas, os problemas de cada ação ou de cada contribuição teórica (CHRISTOV, 2005, p. 33).

A intenção, frente a todo o processo de análise dos registros do Diário de Campo dos(as) estagiários(as), é a possibilidade de construir uma teoria que contribua para repensar as práticas docentes de alfabetização/letramento na EJA, 
que segundo Christov (2005), se dá na medida em que se têm condiçóes de questionar o que foi lido, visto e vivido. Para tanto, os(as) educadores(as) tiveram apoio nas discussóes teóricas junto aos professores(as) da UFPR, da escola, dos(as) educandos(as) de EJA e estagiários(as), como, problematizadores do fazer docente. O relato analítico, fundamentado teoricamente, procurou desvelar o processo inicial e contínuo, do fazer pedagógico, tendo como referência concreta as experiências e vivências na escola de EJA aqui apresentadas.

O estagiário ao tomar conhecimento do ambiente educacional em que iria desenvolver sua prática de docência, buscou se situar e se informar sobre aspectos pedagógica e didaticamente significativos. Para tanto, precisou viver o espaço da instituição escola, principalmente o cotidiano do grupo de profissionais, passando a conviver na comunidade escolar, que de alguma forma interferiu no desenvolvimento da profissionalidade docente.

No estágio, a observação e diagnose das situaçóes teórico-práticas de ensino e aprendizagem vivenciadas junto aos professores-regentes e aos alunos da escola de estágio, foram registradas no Diário de Campo. O plano de ação interventiva foi produzido a partir da análise dos registros no diário, do relatório de estágio, da reflexão-ação, e teve como construtos os registros da observação e diagnose, que se desenvolveu em parceria com a comunidade escolar, professores(as), regente de classe e da universidade, alunos(as) da EJA e estagiários(as). "Considerar a vivência significa imergir e buscar identificar, conhecer e compreender o significado e o sentido dos acontecimentos escolares. Pressupóe conhecer as pessoas envolvidas e também o significado e o sentido que elas dão aos acontecimentos vivenciados" (PENIN, 2009, p. 15).

Muitas vezes, o docente não dá conta do significado das açóes, portanto, o olhar é preciso, mas ele deve ser ampliado de um ver epistemológico. Essa forma de ver é composta de diferentes olhares sobre a realidade. Cada um vê o mundo com que pode e com o que tem e, de nada adianta conceitos prontos e memorizados, se a expressão do sujeito não for vista e sentida por ele (FREIRE, 1997).

A incursão na realidade da escola de jovens e adultos, no período noturno, no Estágio Supervisionado na disciplina de Prática de Ensino dos anos iniciais do Ensino Fundamental, que corresponde do $1^{\circ}$ ao $4^{\circ}$ anos, tem como objetivo a formação profissional do(a) professor(a), com o desafio de buscar, num esforço conjunto, formas de integração das disciplinas pedagógicas com as de conteúdos específicos, tanto ao nível interno do currículo do curso de Pedagogia quanto em nível externo, à realidade da EJA. 
No transcorrer da Prática de Docência e Estágio Supervisionado, vai sendo assumido o compromisso de uma contribuição qualificada e mais sistematizada para a explicitaçẫo do projeto de emancipação humana, a ser efetivado, de modo a buscar e instaurar uma relação dialógica mais efetiva entre a Universidade e a escola de EJA, envolvidas nesse processo. O objetivo é tornar o movimento dialético teoria e prática possível e articulado, integrando de forma organizada a compreensão científica e técnica ao significado social da educação de jovens e adultos.

\begin{abstract}
A incursão na realidade permite uma aproximação do concreto para desvendá-lo, [...] deve permitir o aparecimento das múltiplas relaçóes, [...] tomando a prática como base do real do conhecimento, que parte da realidade próxima, que gera fatos concretos (linguagem, conceituação, conflitos, anseios, esperanças) que transita para o contexto teórico, no sentido de haja apropriação/ recriação desses fatos midiatizados pelo conhecimento, que implica compreensão em níveis cada vez mais profundos e elaborados da essência e das relaçóes desta realidade (FREIRE, 1990, p. 48).
\end{abstract}

O tempo presente na escola é sempre um momento de possibilidades, por isso é preciso tomar em consideraçấo as linhas básicas desse presente que demarcam a construçáo da histórica desse contexto (FREIRE, 1990). Portanto, considerando que a escola de EJA, historicamente constituída de profissionais que nela vêm atuando, muitas vezes sem formaçáo específica, e no seu espaço outros profissionais se formarão, é importante que as Instituiçóes de Ensino Superior (IES), responsáveis pela formação de novos docentes, que atuarão nesse mesmo espaço e tempo, repensem o processo de formação nesse contexto social.

O Diário de Campo do estágio na prática docente tem como objetivo explicitar os aspectos pedagógicos, institucionais e sociais da ação do sujeito que foram interferindo na sua constituição como sujeito, do estudante estagiário(a), e na constituição do sujeito profissional. $\mathrm{O}(\mathrm{a})$ professor(a) regente (HADJI, 1994), registrado em todo transcurso do processo, de forma detalhada e reflexiva, o espaço onde o(a) estagiário(a) retrata suas vivências na escola, relata e avalia os recursos pedagógicos criados ou que foram sugeridos pelos envolvidos na disciplina. 
Dessa forma, a análise dos relatos procurou identificar, na comunicação pedagógica, a dimensão significativa da observação, do planejamento, da intervenção e da avaliação do processo de ensino e aprendizagem na área de conhecimento da alfabetizaçáo/letramento.

A orientaçáo para escrever os relatos foi de que o mesmo atendesse a rigorosidade metódica, e que a sistematização expressasse julgamentos, com base nas experiências vividas e sentidas nas práticas de alfabetização/letramento nas salas de EJA.

Assim sendo, os relatos foram organizados a partir da análise da caracterização da escola, revelando a estrutura e funcionamento, a composição da equipe pedagógica, o horário de atendimento aos alunos da EJA, o número de alunos por turma, séries atendidas, perfil dos(as) professores(as) o grau de escolaridade dos(as) mesmos(as) e o tempo de magistério na rede municipal e na alfabetização de jovens e adultos.

Analisando a caracterização das vinte e nove escolas, verificou-se que apenas três delas atendem a EJA em escolas do centro da cidade, enquanto as outras vinte e seis estão situadas nas sete regionais de Curitiba, escolas da rede municipal, ou em prédios de escolas estaduais que foram municipalizadas, atendendo os anos iniciais do Ensino Fundamental. Em vinte e três escolas, as turmas do $1^{\circ}$ ao $4^{\circ}$ ano de EJA analisadas sáo atendidas no período noturno e em regime multisseriado. Em seis escolas as turmas são organizadas em grupos de $1^{\circ}$ e $2^{\circ}$ anos, e $3^{\circ}$ e $4^{\circ}$ anos, tendo um(a) docente para cada agrupamento de duas séries.

A estrutura das escolas, no período noturno, tem a presença diária da vice-diretora junto aos docentes, sendo que em poucas escolas a secretaria, a biblioteca e a sala de informática funcionam no referido período. Verificou-se que em cinco escolas, a equipe pedagógica permanece durante todo o período noturno, todos os dias. Todas as escolas oferecem merenda escolar, o que difere sâo os horários em que a merenda é oferecida. A maioria das escolas de EJA oferece a refeição antes do início do período de aula, no sentido de atender os(as) alunos(as) que vem do trabalho direto para escola.

As turmas iniciam o ano letivo em média com quinze alunos(as) por turma, sendo que o número de mulheres é consideravelmente maior que dos homens. No segundo semestre, a partir do mês de julho, a frequência de alunos(as) diminui em cerca de $30 \%$, tendo como uma das justificativas, as 
noites frias e chuvosas do inverno curitibano. Nos meses finais do ano letivo, de outubro e novembro, a evasão aumenta, atingindo outros $30 \%$ do número de alunos(as) que iniciaram o ano letivo, ou seja, no final do ano a turma de alunos se reduziu a quase um terço do número inicial. Dentre os motivos mais apontados por alunos e professores para essa evasão estão a oportunidade de trabalho temporário, cujas vagas aparecem nessa época do ano. As idades dos alunos variam de quinze a setenta anos, havendo alguns poucos alunos(as) com idade acima de setenta anos.

O perfil de formação de todos os(as) professores(as) é de nível superior, sendo que apenas quatro professoras não possuem pós-graduação, que é o maior grau de escolaridade dos(as) mesmos(as). O tempo médio de magistério na rede municipal é de oito anos, e a atuação na alfabetização de jovens e adultos é em média de quatro anos. Os(as) professores(as) atuam no regime integral de trabalho, isto é, a matrícula do docente é no período diurno e o período noturno fica como complementaçáo do trabalho.

Segundo a apresentação dos relatos, o planejamento da ação de intervenção pedagógica, desenvolvida na prática de docência, tomou como referência o percurso do estágio de docência, partindo do trabalho e da ótica do(a) professor(a) regente sobre letramento, buscando na maioria das classes uma intervenção que superasse o observado, diagnosticado e registrado.

A Estagiária de número 1 (2013) relatou que no dia de permanência do regente, um dia de trabalho de quatro horas, que é dedicado ao planejamento, frequência a cursos e demais tarefas pedagógicas, outra professora assume a turma e desenvolve um trabalho sem relação com o trabalho da regente.

Senti, nitidamente, uma grande diferença de metodologia entre as duas professoras. Esta ficou grande parte do tempo conversando com os alunos sobre os mais diversos assuntos... Não que náo seja importante este contato, mas acho que, na verdade, isto demonstrou sua falta de planejamento. Após este periodo de conversa, ela distribuiu atividades como cruzadinhas, jogo dos sete erros, caça-palavras, com temas infantis [...] e, como fizeram rápido, pediu para que colorissem os desenhos, para desenvolver a coordenaçáo motora. Foi constrangedor, presenciar 
aquelas pessoas que estavam ali para, de certo modo, "recuperar o tempo perdido" realizando atividades tâo sem propósito. Após os alunos termirarem as atividades propostas, a professora continuou conversando sobre outros assuntos, aguardando o término do horário (ESTAGIÁRIA 1, 2013, grifo nosso).

Tomando como elementos de análise o grifado no relato acima, percebe-se a contradição entre as colocaçôes "Não que não seja importante este contato"e "isto demonstrou sua falta de planejamento", e nos leva aos seguintes questionamentos: Como a estagiária vem entendendo planejamento, se não considera importante o contato entre a regente e os alunos? No entanto, como não foi colocado o assunto tratado na conversa, a estagiária classificou o assunto como não sendo pertinente à sala de aula. Tanto é assim que as atividades propostas, na sequência, parecem revelar que a aula não tinha um bom planejamento.

Já as colocaçôes: "como fizeram rápido, pediu para que colorissem os desenhos, para desenvolver a coordenação motora", "recuperar o tempo perdido" e "realizando atividades tão sem propósito", revela uma percepção maior da estagiária, pois notou que as atividades talvez não estivessem de acordo com a proposta de um processo de alfabetizaçáo voltado para o domínio da leitura e da escrita, tal como elas se apresentam no contexto social. Dessa forma, a atividade pedagógica proposta com a finalidade de desenvolver a coordenaçáo motora fina e a pintura dos desenhos, podem ser consideradas atividades infantis, de grande importância para as crianças, porém, estão em discordância com uma prática social de leitura e escrita voltada para jovens e adultos.

Quanto ao trabalho isolado das duas regentes, percebe-se que elas não são participantes de um processo ativo e interativo de construçáo de significados de um trabalho pedagógico de intervenção coletiva na escola, espaço que deve ter compromisso de todos, objetivando uma aprendizagem crítica e significativa, tanto do educando quanto do educador, "pois, não há docência sem discência" (FREIRE, 1997, p.15). A intervenção pedagógica da professora do período de permanência, postura exigida à estagiária, deveria ocorrer com base em leituras, observaçóes, registros e planos construídos em diferentes períodos com a regente de classe, e não com posturas de quem sabe, ou não, e está improvisando, mas 
de profissionais que tem autonomia, discernimento, rigorosidade metódica e saberes necessários à prática docente (FREIRE, 1997).

Os jovens e adultos sabem que ler e escrever possibilita melhor inserção no mercado de trabalho, frente à competitividade e exigências do mundo de produção capitalista, Dessa forma, a EJA deve assegurar o acesso ao conhecimento escolar. Porém, é preciso repensar as metodologias de ensino, é necessário priorizar a formação de professores para atender as especificidades da escola de EJA, sendo "necessário compreender a forma de atender a identidade cultural e a diversidade dos sujeitos da EJA, de forma que, os jovens e adultos possam estar na escola e aprender" (FARIAS, 2010 apud PRADO; REIS, 2012, p. 2-3). Para tanto, é necessário que o docente tenha clareza do perfil do educando, o conhecimento da realidade em que está inserido, e ter esses "conhecimentos como ponto de partida das açóes pedagógicas, devendo repensar os currículos e os processos avaliativos, como também, as metodologias e materiais didáticos adequados às suas necessidades" (SOARES, 2005, p. 27).

Portanto, buscando formar um profissional mais qualificado e autônomo, em condiçóes de compreender e atuar de maneira mais efetiva sobre a diversidade cultural, tendo como princípio a formação humana como processo bastante amplo, exige-se do professor e da escola um maior domínio de saberes inerentes ao conhecimento didático pedagógico. Fundamentarse com leituras, numa perspectiva teórico-prática, é preciso, pois o objetivo é formar o profissional docente de EJA, a partir de um estudo crítico da dinâmica do processo pedagógico da escola, de observação, diagnóstico e registro do cotidiano da sala de aula e planejamento participativo de ação, necessárias à elaboração, desenvolvimento e avaliação de um projeto de intervenção. Para tanto, é preciso considerar que:

A leitura verdadeira me compromete de imediato com texto que a mim se dá e a que me dou e de cuja compreensão fundamental me vou tornando também sujeito. [...] Daí que seja táo fundamental conhecer o conhecimento existente quanto saber que estamos abertos e aptos à produção do conhecimento ainda não existente (FREIRE, 1997, p. 15).

A fala do mestre propóe aproximar os(as) estagiários(as) dos objetos cognoscíveis, construídos pelos teóricos a partir do cotidiano pedagógico 
escolar vivenciado por eles, para que se realize a construção de novos saberes, via intervenção pedagógica, procurando elucidar a realidade social, econômica, política, científica e educacional da escola, campo de estágio, visando a educação do sujeito cognoscente, isto é, aquele que produz conhecimento comprometido com a teoria e a prática real, tornando-se produtor de novos saberes, pois há diferença entre o vivido-produzido por diferentes sujeitos. "É preciso que o (a) educando (a) vá assumindo o papel de sujeito da produção de sua inteligência do mundo, [...] reconhecer-se como arquiteto de sua própria prática cognoscitiva" (FREIRE, 1997, p. 16).

O relato da estagiária de número 2 (2013) a partir da vivência na sala de EJA é de que:

[...] a professora pediu que en ajudasse dois alunos que estavam fazendo contas de matemática e problemas de matemática no caderno, os dois tinham muita facilidade com as contas, mas apresentavam dificuldades para entender o enunciado dos problemas de matemática. Ocasionalmente precisava ajudar algum dos alunos que estäo mais avançados. Depois passei a auxiliar somente um destes alunos em liçöes de português e entendi que as dificuldades dele com o enunciado dos problemas eram também devido ao seu nivel de alfabetização, pois ele só escrevia as letras se eu fosse soletrando uma a uma e tinha grande dificuldade de ler. (ESTAGIÁRIA 2, 2013, grifo nosso).

Uma situação bem comum durante o período de estágio é a solicitação das regentes para que as estagiárias atendam os alunos com mais dificuldade. Porém, essa é uma situação incoerente. Por que a regente que conhece mais o aluno, que é a pessoa com mais formação e experiência, não se ocupa com os alunos que precisam de maior atenção? As estagiárias ainda estão estudando e podem náo dominar o conhecimento para diagnosticar a dificuldade do aluno, bem como escolher a melhor forma de fazer a intervenção. No entanto, é sempre essa a atividade solicitada às estagiárias. Apesar disso, a estagiária demonstrou sensibilidade e conhecimento ao constatar que o aluno náo sabia ler e escrever e por isso tinha dificuldade com a resoluçáo dos problemas.

A estagiária de número 3 relatou a situação em que a regente lhe sugeriu utilizar um material didático, alfabeto móvel, com um aluno com dificuldade de aprendizagem: 
A professora sugeriu que utilizássemos os alfabetos móveis disponiveis na sala para orientar os alunos na atividade que eles teriam de realizar. Fiquei orientando um aluno somente, este já entendia o conceito de vogal e consoante e que as consoantes $e$ as vogais formam as silabas, mas ainda náo conseguia distinguir o som que cada combinação iria formar. Por exemplo, no caso de "panela" mesmo que eu dissesse que a primeira letra era o P ele náo conseguia saber com qual vogal esta deveria se juntar. Fomos então fazendo as liçôes com calma, ele procurando identificar as letras para formar as palavras com o auxilio do alfabeto móvel. Ao final da noite ele já estava identificando bem as vogais e razoavelmente bem as consoantes, mas conforme a professora me falou depois, isto náo significa que ele vai saber na próxima aula, é um processo lento, mesmo porque conforme a professora alguns alunos provém de classes especiais e necessitam de um tempo mais longo para reter o aprendizado. (Estagiária 3, 2013, grifo nosso).

A estagiária de número 3 demonstrou pouco conhecimento do processo de construção da escrita alfabética, pois, não adianta ensinar as letras, vogais e consoantes, fora das palavras, porque náo existe apoio de significado que auxilie a memorização da informação do nome e do traçado da letra. A recomendação é que se escolham palavras significativas, como o próprio nome e o de familiares, a cidade em que nasceu etc., para escrever para o aluno e dentro dessas palavras destacar as letras que compóem a palavra. Primeiramente se trabalha com a letra inicial e, à medida que o aluno vai identificando mais letras, volta-se aos nomes para fazer a identificação das outras letras.

A referência ao domínio do conceito de consoante e vogal pelo aluno é desprovida de base teórica. O conceito de vogal e consoante é altamente técnico, em termos linguísticos, e não está ao alcance do aprendiz inicial da leitura e escrita. Como poucos professores alfabetizadores sabem que a vogal é a letra cujo som passa livremente pelo aparelho fonador, no momento de sua articulação. Já as consoantes são as letras cujo som recebe alguma constrição do aparelho fonador, seja das cordas vocais, da língua, dos dentes, ou dos lábios, na sua articulaçáo. Além disso, as consoantes isoladas não formam uma sílaba, que é unidade de articulação da nossa língua, por essa razão não se consegue pronunciá-la sem a adiçáo de uma vogal. Portanto, nenhum aprendiz pode dominar o conceito de 
vogal e consoante até porque esse conceito não é necessário para aprender as letras. Para aprender as letras é necessário memorizar a grafia, o nome dela associado a uma palavra com significado, no vocabulário do aprendiz. Posteriormente, quando o aluno entra na fase silábica, ele passa a perceber o som das letras e a relacioná-los ao traçado. É por essa razão que cobrar a memorização de uma letra, sem saber em que palavras ela aparece, não surte efeito. No dia seguinte o aluno esquecerá o "treino realizado". O problema da não aprendizagem não é uma questão de tempo ou de limitação do aluno da EJA e sim da utilização de uma metodologia de ensino ultrapassada (BRANCO; SIMONIAN, 2009).

Um dos problemas em relação ao letramento de jovens e adultos está na falta de vivência dos professores no cotidiano dos alunos. Ressaltando que essa prática requer muitas discussóes e estudos. No que diz respeito ao professor, "[...] essas condiçóes tem a ver com sua formação, com a percepção de si mesmo e de seu papel na escola, com sua interação em relação ao conhecimento, aos alunos, ao espaço da sala de aula" (PEREIRA, 2005, p. 25).

O relato da estagiária de número 4, retrata como a professora regente organizou o trabalho pedagógico de alfabetização na EJA. Ela solicitou a formação de um grupo de cinco alunos em processo de alfabetização e pediu que a estagiária os ajudasse com uma série de atividades utilizando o alfabeto móvel como material de apoio. Segundo o relato, as primeiras atividades eram relacionadas ao reconhecimento de vogais, com a escrita de palavras como "aviäo, elefante, entre outras iniciadas por vogais". A segunda atividade era a utilização de sílabas separadas em quadrados com desenhos carimbados, os mesmos utilizados na Educação Infantil, e os alunos tinham de conseguir formar as palavras indicadas pelos desenhos. O grupo era formado por alunos(as) em estágios diferentes, apresentando dificuldades, abaixo relacionadas:

Aluno 1 - escreve já em letra cursiva, reconhece as vogais, as consoantes e as silabas. Confunde somente algumas silabas parecidas como " $P A$ " " $B A$ " " $L A$ ".

Aluno 2 - escreve em letra cursiva, mas mistura com letra de forma, sabe a diferença entre vogais e consoantes e como se formam as silabas, mas ainda tem grande dificuldade de associar cada silaba ao seu som e ainda escreve engolindo algumas vogais quando o som da consoante é igual ao da silaba. Exemplos de escrita "KVALO" "BLO" para "CAVALO" E "BELO" 
Alunos 3 e 4 - entendem as vogais, que existe relação entre as consoantes e as vogais para formar as silabas, mas não sabem o som de praticamente nenhuma consoante ou conjunto de consoante e vogal. Se forem auxiliados a escrever "PANELA" e tiverem em seguida de escrever "JANELA" entendem que só a primeira silaba mudou, mas não sabem qual letra utilizar.

Aluno 5 - entende que os sons são divididos nas palavras em silabas, que a maior parte das silabas são formadas por 02 letras, mas ainda não entendeu completamente a relação de consoantes e vogais. Consegue entender que "elefante" começa com " $e$ ", mas não que o som "Le" de elefante é composto de " $L+e$. (Estagiária 4, 2013).

A tentativa da estagiária em diagnosticar as dificuldades dos alunos revela, novamente, o pouco domínio teórico de conteúdos da Psicolinguística, em especial da teoria de Ferreiro e Teberosky (1986) e da linguística de Cagliari (1997), conhecimentos fundamentais para realizar essa avaliação. Dessa forma, a estagiária parece valorizar o domínio do traçado da letra cursiva como sendo mais importante que o conhecimento das letras.

$\mathrm{O}$ fato dos alunos misturarem os traçados em letra cursiva e de forma demonstra o equívoco pedagógico de mostrar aos alunos os diferentes tipos de grafia para uma letra, quando só é necessário conhecer um traçado para cada uma das 26 letras do alfabeto. E já está bastante disseminado, na área da metodologia da alfabetização, que o tipo melhor de visualização e de produção é o tipo "de forma". É desnecessário multiplicar a dificuldade em memorizar as 26 letras por dois ou três tipos, pois a cada tipo escolhido, haverá um conjunto de mais 26 traçados a serem aprendidos. Essa atitude resulta em 52 ou 78 diferentes traçados a ser memorizado, se for considerada a apresentação dos tipos de forma e cursiva - maiúscula e minúscula - aos iniciantes da alfabetização. Se já é difícil para os adultos memorizarem 26 traçados, que dizer então de seus múltiplos tipos? Em geral as professoras dizem que têm que ensinar os vários tipos de letra, senão o aluno não consegue ler os diferentes materiais impressos disponíveis no meio social.

Essas afirmaçóes demonstram o desconhecimento de que para aprender a ler é preciso construir um "conceito" de letra. O que só acontece com a vivência com os textos escritos. Uma vez bem dominado um tipo de alfabeto, o aluno será capaz de ler em qualquer tipo apresentado. Será como se faz hoje no 
computador, escolhe-se um tipo de letra para escrever e depois se pode trocar para qualquer outro tipo. Mesmo assim, é possível ler o texto produzido. Isso, é claro, não acontece no início da alfabetização e sim ao longo do processo, de pelo menos dois anos de uso de um mesmo tipo de letra. A informaçáo de que o aluno engoliu a vogal não é correta, porque engolir é retirar, quando o que o aluno faz é acrescentar os sons que ele já aprendeu a escrever (BRANCO; SIMONIAN, 2009).

Ainda sobre o "engolir a letra", é sabido que o alfabeto da língua portuguesa apresenta o princípio acrofônico, na maioria de suas letras. Isto é, o nome da letra veicula o seu som. Se essa característica facilita o conhecimento da relação letra/som, para os iniciantes, essa característica pode ser um problema, porque induz a achar desnecessário colocar a vogal "E" junto da consoante, para formar a sílaba. Somente a seguida reflexáo sobre a necessidade das vogais para a composiçáo da sílaba é que pode levar o aluno a vencer essa induçáo (BRANCO; SIMONIAN, 2009).

Para desenvolver um trabalho de alfabetização de jovens e adultos, é importante considerar o alfabetizando um sujeito que aprende a ler e a escrever produzindo, construindo seu próprio conhecimento sobre a leitura e a escrita do mundo em que vive, e não alguém que nada sabe, no qual o(a) professor(a) deposita um conhecimento da leitura e da escrita. É preciso considerar o alfabetizado aquele que se apropria da escrita, aprende a ler e a escrever com significado, passando da decodificação e da codificação para a leitura e escrita dos textos em língua escrita e falada. Desse modo, apropriar-se da escrita é torná-la própria, pois, assumindo a fala e a escrita como propriedade, própria de si e de seu tempo (SOARES, 2003).

$\mathrm{Na}$ alfabetização de adulto deve-se ter a compreensão da prática democrática e crítica da leitura do mundo e da palavra do educando(a), onde a leitura não deve ser memorizada mecanicamente, mas ser desafiadora, que ajude a pensar e analisar a realidade em que se vive, portanto, "é preciso que quem saiba, saiba sobretudo que ninguém sabe tudo e que ninguém tudo ignora” (FREIRE, 1997 p. 32). Sendo assim, a alfabetização deve ser um processo que respeite as diferentes experiências e níveis de conhecimento de cada alfabetizando, tendo a compreensão de que o aprender a ler e a escrever é um processo individual que não acontece para todos, no mesmo tempo e forma.

O alfabetizador deve sempre buscar, inicialmente, no repertório cotidiano dos alunos, as palavras estáveis para formar um conjunto com o qual irão 
trabalhar com a decodificação e com a codificação. Essa estratégia facilitará o processo de memorizaçâo das palavras e os ajudará a ler e a escrever com maior segurança. Também, é preciso priorizar no trabalho de construção do sistema de escrita alfabética, o trabalho com produção de textos, que ocorre por meio do qual o aluno poderá construir hipóteses essenciais para seu avanço. O que se tem visto em sala de aula de EJA é um trabalho com palavras, frases do repertório das cartilhas infantis e depois textos desconectados do interesse dos alunos. $\mathrm{O}$ texto deve ser o ponto de partida, pois o objeto de estudo e objetivo prioritário tem que ser a leitura, como ensina Soares (2003) e os Parâmetros Curriculares Nacionais de Língua Portuguesa (BRASIL, 1997).

Partindo do princípio de letramento como forma de exercício consciente de cidadania, deve-se levar em conta que letramento é construção de um saber crítico-contextual, orientado para a transformaçáo da realidade, sendo que é necessário pensar a prática pedagógica de letramento fundamentada num diálogo intercultural, pois, o ensinar os jovens e adultos,

[...] sem participação restringe a caminhada conjunta, porque a história é feita com os outros, num tempo de possibilidades e não de determinismo, ou seja, todos deveriam ter seu próprio tempo de falar, seu próprio tempo de fazer, seu próprio tempo de pensar e repensar. [...] quer dizer próprio de seu tempo, de seu jeito, do seu envolvimento. (FREIRE, 1997, p. 25).

Nas práticas de letramento de EJA alunos e professores são sujeitos de construção e apropriação do conhecimento socialmente elaborado, e para que se efetive o letramento é necessário o compromisso de solidariedade e responsabilidade social num trabalho pedagógico coletivo. O relato da estagiária 5, sobre o trabalho pedagógico da professora regente, em uma turma de EJA em escola da periferia de Curitiba, retrata a elaboraçáo de um denominado "Caderno da Novidade", sendo destinado ao relato de um acontecimento importante da vida do educando:

[...] Cada dia a professora perguntava quem tinha uma "novidade" para falar, e convidava quem se oferecia para escrever na lousa o seu relato. Também os outros alunos, participam da escrita, dando ideias de como redigir, bem como, intervindo em questóes do código escrito, propriamente 
dito. Por fim, todos os alunos copiavam em seus cadernos o texto produzido coletivamente. Nesta aula, a aluna $M$. escreveu: "Hoje fui com minha mãe no hospital e ajudei um senhor doente". Após relatar que tinha auxiliado uma pessoa idosa que estava sozinha no hospital, a aluna estava visivelmente sensibilizada com este fato. Enquanto a aluna M. escrevia, o aluno P. escrevia no seu caderno questionando em voz alta: "Hoje é com H? E com G ou J? Hospital também tem H? E é o U ou o L no final?” E depois concluiu, indignado... "Isso é que atrapalha!". (Estágiaria 5, 2013).

A estagiária considerou muito interessante esta iniciativa, porque além dos alunos falarem de suas experiências, tinham a tarefa de escrever um texto com muito significado, e de forma compartilhada com os colegas. Porém, ela percebeu a indignação do aluno ao ter algumas dificuldades na escrita das palavras, no qual percebeu que a língua tem muitas irregularidades, e ela concordou que esta característica é um ponto difícil da aprendizagem, principalmente quando temos que recorrer à memorização para decidir como se escreve.

A melhor técnica de produzir textos coletivos é o aluno "ditar" o texto para um escriba inicialmente a professora ou um aluno que tenha maior domínio da escrita. A professora ao fazer o registro das palavras, pode ir recordando quais as letras necessárias para escrever a palavra desejada, recorrendo às letras iniciais dos nomes dos alunos e a outras palavras já conhecidas. Dessa forma, o aprendiz não se expóe, escrevendo errado na lousa. E os alunos também não ficam sozinhos tentando escrever o que não sabem. Para um iniciante escrever com tranquilidade é preciso contar com a ajuda de quem sabe, neste caso, a professora, que após a escrita faria a leitura do texto, chamaria a atenção para a grafia das palavras difíceis e aproveitaria para explicar que muitas das palavras da nossa língua são mais difíceis de escrever e que é preciso memorizar sua grafia para náo escrever errado. Só entáo os alunos copiariam o texto (BRANCO; SIMONIAN, 2009).

\section{Considerando superação nas práticas de alfabetização/ letramento na EJA}

A intervenção pedagógica é a etapa do estágio em que o estagiário, após observar e acompanhar os alunos durante a execução das aulas da professora 
regente, elabora um planejamento e o executa. Enfim, é o momento em que ele assume a ação como docente na classe de EJA.

A açáo docente de intervenção caracteriza-se como um processo formativo, pois "as ideias de movimento, processo, continuidade, reconstrução, indagação, entre outras, nos remetem a uma concepção de que a formação e a ação docentes estăo estreitamente vinculadas uma à outra" (ESTEBAN, 2007, p. 10).

Entendendo que o estagiário desenvolveu essa etapa com objetivo de mudar, alterando a dinâmica da sala de aula de EJA, cujo foco é deixar de ser o professor como detentor do saber, passando para o educando, em formaçáo docente inicial, como sujeito ativo. Portanto, ele foi constantemente instigado e orientado a refletir sobre sua prática e dificuldades na alfabetização/ letramento, fazendo da sala de aula o seu laboratório de investigação do professor pesquisador, pois entende que

[...] aprender implica a noção de ação, uma ação interior que nem sempre é visível a um observador. Se pudermos constatar e descrever determinadas açôes que nos indicam a presença de certa aprendizagem, estas são apenas traços limitados do complexo processo interno do espírito humano, que constitui a aquisição de um novo saber (MUNIZ, 2002, p. 68).

Em outras palavras, a intervenção deve ser descrita por quem viveu, observou, diagnosticou, analisou os registros, pois, assim os detalhes, os significados e as aprendizagens percebidas são próprios do sujeito da açáo, são de uma riqueza muito grande. Nessa forma de pensar a ação emerge do sujeito-estudante que sente, compreende e é, portanto, chamado a participar e comunicar efetivamente seu processo de aprendizagem. A intervençáo se dá na medida em que há interação entre os envolvidos, agindo e repensando a ação coletivamente em busca da transformação do processo e dos sujeitos.

Sendo que a palavra "trans-form-ação" pode ser compreendida por parte, como: "Trans é um prefixo grego que significa posiçâo contrária no espaço. $\mathrm{Na}$ dialética a categoria contradição é posta quando se considera diferentes modos de ser e de estar no mundo, visto por vários olhares e sujeitos. Forma significa espaços, maneiras, métodos ou procedimentos" (HARACEMIV, 2002. p. 58, grifo nosso). 
Assim sendo, será apresentada, a seguir, uma ação interventiva com objetivo de mostrar que depois de muito ver, pensar e planejar nas interfaces de muitos olhares foi possível superar os obstáculos identificados na prática docente vivida, refletida, na sala de aula de EJA, onde foi acontecendo uma transformação pedagógica no ato de alfabetizar/letrar... "Quem ensina aprende ao ensinar e quem aprende ensina ao aprender" (FREIRE, 1997, p. 25).

De início a professora-regente da classe solicitou a três estagiárias que trabalhassem na intervenção pedagógica, da prática docente, os conteúdos de História, Geografia e Ciências da Natureza.

No primeiro momento as estagiárias estranharam e procuraram as professoras da UFPR, supervisoras e orientadoras do estágio, pois, tinham sido orientadas a trabalhar Matemática e Língua Portuguesa, e tinham somente uma certeza, queriam fazer diferente do que tinham visto até então, pois, “[...] a opção da educadora é democrática, ela sabe que o diálogo não é apenas em torno dos conteúdos, mas sobre a vida; não só é válido do ponto de vista do ensinar, mas formador também de um clima aberto e livre" (FREIRE, 1997, p. 87) no ambiente da classe.

Os vínculos estabelecidos com a turma eram significativos, pois, os educandos da turma já haviam expressado a alegria de tê-las junto a eles, dizendo: "[...] nos dias que vocês vêm nós aprendemos tudo com a ajuda de vocês. Vale muito quando vocês dizem o que é que está escrito no quadro em outras palavras, assim a gente copia sabendo o que está copiando" (ALUNO DA ESCOLA D. A., 2013).

A participação evidencia a motivação do aluno em relação à aprendizagem, contribuindo em muito para o seu sucesso. Havia troca, eles sentiram que tinham espaço para participar ativamente do processo de aprendizagem, num permanente diálogo, tendo a estagiária como uma orientadora de ensino, porque sentiram "abertura respeitosa aos outros e, de quando em vez, de acordo com o momento, tomar a própria prática de abertura ao outro como objeto de reflexão crítica deveria fazer parte da aventura docente" (FREIRE, 1997, p. 153).

Todos se debruçaram para fazer um levantamento bibliográfico de textos que viessem elucidar sobre a alfabetização/letramento em todas as áreas do conhecimento, pois, como já foi explicitado a prática pedagógica na EJA não trabalha com as outras áreas do conhecimento para alfabetizar, somente em 
Língua Portuguesa. As recomendações dos Parâmetros Curriculares Nacionais (PCN) (BRASIL, 1997, p. 30), "é que a escola deve viabilizar o acesso do aluno ao universo dos textos que circulam socialmente, ensinar a produzi-los e a interpretá-los". Assim sendo, o trabalho na EJA deve estar baseado na diversidade textual em diferentes áreas de conhecimentos, desde que sejam trabalhadas de forma interdisciplinar, tornam-se ferramentas fundamentais para a leitura, compreensão de mundo e ampliação da visão da realidade ao educando.

A partir de um referencial teórico, as estagiárias escolheram o tema "Os Movimentos Populacionais", o ir e vir das pessoas, levando em conta que muitos alunos(as) falavam de seus lugares de origem, fazendo muitas relaçōes entre a vida, a denominação das coisas e as relações entre as pessoas, que tinham e que passaram a ter em Curitiba. O objetivo era identificar os lugares de origem dos(as) alunos(as), dos antepassados de suas famílias, levantar os motivos que os levaram a sair de seus lugares de origem (movimento migratório), a história de cada um e a memória de fatos históricos e pessoas importantes dos lugares, a localização no mapa do município e estado do Brasil, a região, as atividades econômicas dos lugares de origem e atualmente, as dificuldades de ambientalização no novo lugar, as mudanças ambientais ocorridas em seus lugares de origem, bem como, as questóes relacionadas à educação, saúde e segurança, comparando hoje com o vivido nos referidos lugares de origem.

Foram necessários quatro dias de aula, distribuídos em duas semanas. Muitos relatos foram registrados, frente aos questionamentos das docentesestagiárias a participação foi muito ativa, com mural de imagens dos lugares, fotos que revelavam a história de todos. Como tinha uma aluna com 70 anos, foi aproveitado as vivências da mesma para realizar uma retrospectiva de fatos históricos ocorridos no Brasil, com a elaboração de um mural com uma linha do tempo. O trabalho com o mapa foi muito interessante, sendo que depois os alunos construíram "croquis", como roteiros dos lugares onde residem atualmente.

As questôes de trabalho, educação, saúde e segurança foram muito discutidas, sendo que já se tinha consciência que essa metodologia de trabalho, não se restringia a ensinar os códigos de leitura e escrita, ou relacionar os sons as letras, como já relatado no Diário de Campo da Estagiária 3 (2013) deste trabalho. Os alunos foram capazes de compreender o significado das questôes discutidas, e aprenderam para usá-las no dia-a-dia, de forma a atender às 
exigências da vida no trabalho, em casa, na comunidade.

Os trabalhos com diferentes textos permitiram aos alunos a leitura e interpretação das informaçóes contidas nos jornais, revistas, livros, tabelas, formulários, carteira de trabalho, contas de água, luz, telefone, confronto das ideias, com informação, orientação de que podem melhorar a memória, pelo uso efetivo da leitura e escrita.

\section{Considerando finalmente as práticas de letramento registradas nos Diários de Campo}

As contribuições das práticas e eventos relatados nos Diários de Campo pelos(as) estagiários(as) da UFPR, em processo de formação docente inicial, junto as escolas da rede municipal de ensino, foram significativas para a compreensão do processo de letramento dos jovens e adultos.

Os relatos apresentados evidenciam que se pode alfabetizar em diferentes áreas do conhecimento letrando, pois, "não é porque os processos de alfabetizaçáo e de letramento sáo diferentes que devem ser sucessivos. O ideal é alfabetizar letrando" (SOARES, 2006, p. 58).

Esse trabalho desvelou a necessária formação docente integral, assim sendo, é importante que os licenciandos em Pedagogia conheçam o funcionamento do sistema de ensino da EJA, trabalhem pela busca do conhecimento a partir das práticas sociais, pois, podem possibilitar aos alunos usar os conhecimentos apreendidos em benefício da expressão e comunicação reconhecidas, necessárias e legítimas no seu dia a dia dentro e fora da escola. "A escola insere o aluno no contexto de diálogo da cultura, para que ele possa participar desse diálogo na condição de produtor de conhecimento entendimento e produzir sentido a vida" (GUEDES; SOUZA, 2006, p. 15).

Nesse sentido, é preciso que os professores da EJA estejam atentos para as questóes relacionadas à alfabetizaçáo e/ou letramento. É necessária a conscientização, tanto da Universidade, como da escola de EJA, com orientaçáo de planejamento coletivo no tempo da hora atividade, que na rede municipal representa $30 \%$ da carga horária semanal do docente. Sendo assim, é fundamental que esse tempo seja utilizado como um espaço de reflexóes e encaminhamentos de açóes pedagógicas, com práticas pedagógicas coerentes com o discurso emancipatório e progressista da educação de jovens e adultos. 


\section{REFERÊNCIAS}

ARROYO, Miguel G. Educaçáo de jovens e adultos: um campo de direitos e de responsabilidade pública. In: SOARES, Leôncio J. G.; GIOVANETTI, Maria Amélia; GOMES, Nilma Lino. Diálogos na educação de jovens e adultos. Belo Horizonte: Autêntica, 2005. p. 19-50.

BRANCO, Veronica; SIMONIAN, Michele. Alfabetização e Linguagem. Universidade Federal do Paraná. Setor de Educação. Coordenaçâo de Integraçẫo de Políticas de Educaçáo a Distância. Curitiba: UFPR/CIPEAD, 2009.

BRASIL. Ministério da Educação. Secretaria de Educação Fundamental. Parâmetros Curriculares Nacionais: lingua portuguesa. Brasília, DF: MEC/SEF, 1997. Disponível em: <http://portal.mec.gov.br/seb/arquivos/pdf/livro02. pdf $>$. Acesso em: $12 \mathrm{dez} .2013$.

BRASIL. Ministério do Planejamento, Orçamento e Gestáo. Instituto Brasileiro de Geografia e Estatística. Síntese de Indicadores Sociais: uma análise das condiçôes de vida da população brasileira. Rio de Janeiro: IBGE, 2012. Disponível em: <ftp://ftp.ibge.gov.br/Indicadores_Sociais/Sintese_de_ Indicadores_Sociais_2012/SIS_2012.pdf>. Acesso em: $12 \mathrm{dez} .2013$.

CHRISTOV, Luiza Helena S. Teoria e prática: o enriquecimento da própria experiência. In: GUIMARÁES, ARCHANGELO, A. et al. O coordenador pedagógico e a educação continuada. 8. ed. São Paulo: Loyola, 2005.

CIRINO, R. B.; HARACEMIV, Sonia M. C.; SOEK, Ana Maria. Prática Pedagógica na Educação de Jovens e Adultos (EJA). Universidade Federal do Paraná. Setor de Educação. Coordenação de Integração de Políticas de Educação a Distância. Curitiba: UFPR/CIPEAD, 2010.

DI PIERRO, Maria Clara. Balanço e desafios das políticas públicas de educação de jovens e adultos no Brasil. In: SOARES, Leôncio (Org.). Convergências e tensöes no campo da formação e do trabalho docente. Belo Horizonte: Autêntica, 2010.

ESTEBAN, Maria Teresa. Educação popular: desafio à democratização da escola pública. Caderno Cedes, Campinas, SP, v. 27, n. 71, p. 9-17, jan./abr. 2007. Disponível em: <http://www.scielo.br/pdf/ccedes/v27n71/a02v2771. pdf $>$. Acesso em: 8 dez. 2013. 

Pedagogia?

FERREIRO, E; TEBEROSKY, A. Psicogênese da língua escrita. Tradução de Diana Myriam Lichtenstein et al. Porto Alegre: Artes Médicas, 1986.

FREIRE, Paulo. A educação na cidade. Sáo Paulo: Cortez, 1987. . Extensão ou comunicação? Rio de Janeiro: Paz \&Terra, 1990. Terra, 1991 Ação cultural para a liberdade e outros escritos. Rio de Janeiro: Paz \& Pedagogia da autonomia: saberes necessários à prática educativa. São Paulo: Paz \&Terra, 1997.

CAGLIARI, Luiz Carlos. Alfabetização e Linguistica. São Paulo: Scipione, 1997.

GUEDES, Paulo Coimbra; SOUZA, Jane Mari de. Leitura e escrita são tarefas da escola e não só do professor de português. In: NEVES, Iara C. Bitencourt (Org.). Ler e escrever: compromisso de todas as áreas. 8. ed. Porto Alegre: UFRGS, 2007. p. 17-22.

HADDAD, Sergio. Sergio Haddad no Fórum Mundial de Educação. Fórum Mundial da Educação: Crise Capitalista, Justiça Social e Ambiental. Porto Alegre, 2012. Entrevista concedida ao Fórum Mundial da Educação. Disponível em: <fmejsa.forummundialeducacao.org/?p=949>. Acesso em: 20 jan. 2014.

HADJI, Charles. A avaliação, regras do jogo: das intençôes aos instrumentos, Porto, 1994.

HARACEMIV, Sonia M. C. O Professor e o Programa de EJA de Curitiba: repensando o que é afirmado, negado e sugerido. 2002. 181 f. São Paulo. Tese (Doutorado em Educação) - Pontifícia Universidade Católica de São Paulo, São Paulo, 2012.

KLEIMAN. Angela B. Os significados do letramento: uma nova perspectiva sobre a prática social da escrita. Campinas, SP: Mercados de letras, 1995.

MARCUSCHI, Luiz Antônio. Comunicaçôes e informaçôes: teleducação e o trabalhador. Revista Brasileira de Estudos Pedagógicos, Brasília, DF, v. 76, n. 184, set./dez. 1995. Disponível em: <http://rbep.inep.gov.br/index.php/RBEP/ article/viewFile/512/523>. Acesso em: 12 dez. 2013. 
MUNIZ, Sodré Araújo. Antropológica do Espelho. Petrópolis, RJ: Vozes, 2002.

PENIN, Sonia. Profissão docente e contemporaneidade. In: PENIN, Sonia; MARTINEZ, Miguel; ARANTES, Valéria A. (Org.). Profissáo Docente: pontos e contrapontos. São Paulo: Summus, 2009.

PEREIRA, Marina Lúcia C. A construção do letramento na educação de jovens e adultos. Belo Horizonte: Autêntica, 2005.

PRADO, Di Paula Ferreira; REIS, Sônia M. A. Oliveira. Educação de jovens e adultos: o que revelam os sujeitos? In: ENCONTRO NACIONAL DE DIDÁTICA E PRÁTICAS DE ENSINO, 16., 2012, Campinas. Anais... Campinas, SP: UNICAMP, 2012. Disponível em: <http://www.infoteca. inf.br/endipe/smarty/templates/arquivos_template/upload_arquivos/acervo/ docs/3479p.pdf>. Acesso em: 12 dez. 2013.

SOARES, Magda. Letramento e escolarização. In: RIBEIRO, Vera Masagão (Org.). Letramento no Brasil. São Paulo: Global, 2003. Alfabetização e letramento. São Paulo: Contexto, 2005. Letramento: um tema em três gêneros. 2. ed. Belo Horizonte: Autêntica, 2006. 


\section{L'alphabétisation dans I'Éducation des Jeunes e des Adultes: ce qui est revélé par les journaux de la pratique quotidienne de l'enseignement effectuée dans le cadre du Cours de Pédagogie?}

\section{Résumé}

Cet article vise à présenter une recherche sur les pratiques de littératie observées, diagnostiquées et enregistrées dans les journaux de la pratique quotidienne de l'enseignement, relatives aux classes multigrades du programme Educação de Jovens e Adultos (EJA) [Éducation des jeunes et adultes] dans les écoles municipales élementaires de Curitiba (Brésil). Ces journaux ont été écrits par les étudiants du Cours de Pédagogie de l'Universidade Federal do Paraná. Il s'aggit d'une étude qualitative dans les lignes de la recherche-action, sur la relation entre le concept théorique de littératie des universitaires et l'expérience pratique dans les classes de l'École Elémentaire, au contexte de la Discipline de Pratique de l'Enseignement. Les dossiers analysées indiquent que les enseignants et les stagiaires de l'EJA ont besoin de connaître les pratiques de littératie de ses élèves, pour organiser une pratique pédagogique d'intervention. Cela aura pour but de faire que l'alphabétisation dans l'EJA provienne de la littératie des relations sociales, avec des possibilités d'accroître la participation et
Literacy in youth and adult education: what do practice teaching field diaries of the graduate course of pedagogy reveal?

\section{Abstract}

This article aims to present a survey about literacy practices observed, diagnosed and recorded in the Field Diaries by undergraduates of the Course of Pedagogy, at the Federal University of Paraná. The classes which were observed are the mixed classroom of the Youth and Adults Education Program - YAE at the municipal schools of Curitiba. This is a qualitative action research, which investigates the relationship between the theoretical conception of literacy that academics of the discipline of Teaching Practices in Early Years of Elementary School have, and the real practice in classrooms. In this research, the analyzed records indicate the need for YAE teachers and trainees to know the literacy practices in which their students are inserted in their everyday relationships, organizing the educational interventional practice, so that literacy in adult education come from their social relations, with the possibility of expanding the participation and emancipation of young and adult understanding of the contextual dimensions of the world in which they live. So speaking and writing will be meaningful to the subjects who perform it.

Keywords: The Youth and Adults Education. Teaching Practices. Literacy. 
d'agir sur l'émancipation des adolescents et des adultes, par la compréhension des dimensions contextuelles du monde dans lequel ils vivent, de sorte que la parole et l'écriture soient significatifs pour ces sujets, qui les pratiquent.

Mots-clés: Education des jeunes et

adultes. Pratique de l'enseignement.

Littératie.

\section{Sonia Maria Chaves Haracemiv}

E-mail: sharacemiv@gmail.com

\section{Veronica Branco}

E-mail:veronica_branco@hotmail.com

Recebido em: 9/12/2013

Versão final recebida em: 18/2/2014

Aprovado em: 19/2/2014 